\title{
HETEROCYCLES 43. SYNTHESIS, CHARACTERIZATION AND ANTIOXIDANT ACTIVITY OF SOME THIAZOLE HYDROXYCHALCONES AND THEIR FLAVONOIDIC DERIVATIVES
}

\author{
TEODORA CONSTANTINESCU ${ }^{1}$, DENISA LEONTE ${ }^{1}$, LÁSZLÓ CSABA BENCZE ${ }^{2}$, LAURIAN \\ VLASE $^{3}$, SILVIA IMRE ${ }^{4}$, DANIELA HANGANU ${ }^{5}$, VALENTIN ZAHARIA $^{1}{ }^{*}$ \\ I "Iuliu Hațieganu" University of Medicine and Pharmacy, Department of Organic Chemistry, 41 Victor Babeș Street, Ro- \\ 400012 Cluj-Napoca, Romania \\ 2 "Babeș-Bolyai" University, Faculty of Chemistry and Chemical Engineering, Biocatalysis and Biotransformation Research \\ Group, 11 Arany János Street, Ro-400028 Cluj-Napoca, Romania \\ 3 "Iuliu Hațieganu" University of Medicine and Pharmacy, Department of Pharmaceutical Technology and Biopharmacy, 41 \\ Victor Babeș Street, Ro-400012 Cluj-Napoca, Romania \\ ${ }^{4}$ University of Medicine and Pharmacy, Department of Analytical Chemistry and Drug Analysis, 38 Gheorghe Marinescu \\ Street, Ro-540139 Târgu Mureș, Romania \\ 5 “Iuliu Hațieganu” University of Medicine and Pharmacy, Department of Pharmacognosy, 12 Ion Creangă Street, Ro- \\ 400010 Cluj-Napoca, Romania
}

*corresponding author: vzaharia@umfcluj.ro

\begin{abstract}
Natural and synthetic chalcones are biologically active molecules, as well as precursors for the preparation of several pharmacologically useful compounds, belonging to the class of the epoxides, flavanones, flavones and aurones. The thiazole ring is present in the structure of many compounds with therapeutic potential. Starting from these premises, the aim of this study was the synthesis and characterization of new thiazole chalcones, flavanones and flavones and the evaluation of their antioxidant potential. Chalcones were obtained by applying the Claisen-Schmidt condensation of thiazole aldehydes with acetophenones substituted in ortho or para with a hydroxyl group. The ortho hydroxychalcones were used as precursors for the synthesis of thiazole flavanones and flavones, in different reaction conditions: flavanones were obtained by cyclization in acidic/basic catalysis and flavones were obtained by oxidative cyclization with iodine in dimethylsulfoxide (DMSO). The structures were confirmed by ${ }^{1} \mathrm{H}$ NMR, ${ }^{13} \mathrm{C}$ NMR, IR and MS analysis. The antioxidant activity was determined by 2,2-diphenyl-1-picrylhydrazyl (DPPH) free radical scavenging method. The synthesized compounds have a low antioxidant activity.
\end{abstract}

\section{Rezumat}

Calconele naturale și de sinteză sunt molecule biologic active și precursori pentru sinteza unor compuși din clasele epoxizilor, flavanonelor, flavonelor și auronelor. Nucleul tiazolic este prezent în numeroși compuși cu proprietăți terapeutice. Pornind de la aceste premize, au fost sintetizate și caracterizate o serie de calcone, flavanone și flavone tiazolice și s-a evaluat potențialul lor antioxidant. Calconele au fost obținute prin reacția de condensare Claisen-Schmidt a unor aldehide tiazolice cu acetofenone substituite în orto sau para cu o grupă hidroxil. Orto hidroxicalconele au fost utilizate ca precursori pentru sinteza flavanonelor și flavonelor tiazolice, în diferite condiții de reacție: flavanonele s-au obținut prin ciclizare în cataliză acidă/ bazică, iar flavonele s-au obținut prin ciclizare oxidativă cu iod în dimetilsulfoxid (DMSO). Structurile au fost confirmate prin analize ${ }^{1} \mathrm{H}$ RMN, ${ }^{13} \mathrm{C}$ RMN, IR și MS. Activitatea antioxidantă a compușilor sintetizați a fost determinată prin metoda neutralizării radicalul liber 2,2-difenil-1-picrilhidrazil (DPPH). Compuşii sintetizaţi au o activitate antioxidantă redusă.

Keywords: Chalcone, Flavone, Flavanone, Thiazole, Spectral analysis

\section{Introduction}

Flavonoids are a group of natural and synthetic compounds exhibiting $\mathrm{C}_{6}-\mathrm{C}_{3}-\mathrm{C}_{6}$ frame [16]. Depending on the chemical structure, flavonoids are classified in: flavanones, flavones, chalcones, anthocyanidins, flavonols, flavanonols (dihydroflavonols), isoflavones and flavanols (flavan-3-ols /catechins) [10].

Chalcones, 1,3-diphenyl-2-propen-1-ones, are available in many conjugate forms in nature. The two aromatic moieties are joined by an $\alpha, \beta$-unsaturated carbonyl bridge of three carbon atoms. The most common method for the synthesis of chalcones is the ClaisenSchmidt condensation reaction of benzaldehydes and acetophenones. The reaction takes place in basic or acidic catalysis [15]. Butein, a natural tetrahydroxychalcone, is known to inhibit lipid peroxidation. Also, its ability to reduce DPPH stable radical is similar with $\alpha$-tocopherol [9].

Chalcones and their derivatives are known for their diverse applications, because of the antioxidant, anti- 
inflammatory, analgesic, anti-platelet, anti-ulcer, antibacterial, anticancer, antiviral, antihyperglycemic, antiHIV properties and so forth [17]. Due to the presence of vinyl keto reactive group, chalcones show antioxidant properties. In eukaryotic cells, Michael type additions are responsible for specific effects of the chalcones [24]. The antioxidant activity of chalcones is influenced by the aryl groups and their substitution patterns [25].

Flavanones are generally obtained by the cyclization of chalcones substituted in ortho position with a hydroxyl group. The reaction is carried out in acidic or basic catalysis, thermal, photochemical or electrochemical processes. Hesperidin is a natural flavanone with outstanding therapeutic properties [12, 13]. Hesperidin derivatives have been reported for their anti-inflammatory, antimicrobial, antioxidant, anticancer, cardioprotective, hepatoprotective, nephroprotective, neuroprotective and antiarthritic effects [1]. Flavones may be synthesized by oxidative cyclization of ortho hydroxychalcones with iodine in DMSO [7]. Among natural flavones, quercetin is known for its antioxidant activity, being able to neutralize highly reactive species, such as hydroxyl and peroxynitrite radicals [6].

The thiazole ring is present in the structure of a large number of compounds with antioxidant properties, antimicrobial, anti-inflammatory and antitumor activities. This heterocycle is present in both natural compounds (vitamin $\mathrm{B}_{1}$, bleomycins) and synthetic compounds (sulfathiazole, cefotaxime and so forth) recognized for their pharmacological value. Recently, it was reported that a series of 3,4,5-trimethoxyphenylazetidin-1,3thiazole-2,4-diamine derivatives presented antioxidant activity comparable with ascorbic acid [11]. The antioxidant properties of thiazole compounds are accomplished in two ways: by neutralizing free radicals and by inhibiting lipid peroxidation [11, 13, 20, 24]. Antioxidants are molecules capable of inhibiting the oxidation of other molecules, in this way preventing cell death and other several pathologies determined by the presence of free radicals. The free radicals (superoxide, hydroxyl radicals), hydrogen peroxide and lipid peroxidation are known to cause various pathologies, such as asthma, cancer, cardiovascular diseases, diabetes, inflammatory processes and periodontology. The antioxidant activity of natural flavonoids, including chalcones, is exercised through different mechanisms, such as free radicals neutralization, hydrogen transfer and chelating metal ions. The antioxidant properties of chalcones are influenced by the volume of the two subunits and the nature of the substituents grafted on the aromatic rings. The hydroxyl group has a key-role in the antioxidant activity due to its easy conversion to the phenoxyl radical by a hydrogen transfer mechanism [21].

The 2,2-diphenyl-1-picrylhydrazyl (DPPH) free radical scavenging assay is currently used in order to evaluate the antioxidant activity of various synthetic compounds and natural products [8]. The method is based on the measurement of the capacity of antioxidants to neutralize the DPPH radicals. DPPH is a stable free radical, which can be reduced by accepting an electron/hydrogen atom, becoming a stable molecule, diamagnetic. DPPH radical has a strong absorption band at $517 \mathrm{~nm}$, while the reduced form does not absorb at $517 \mathrm{~nm}$. When DPPH accepts an electron/hydrogen atom from the antioxidants, the odd electron of the nitrogen atom becomes paired off and the initial deep violet solution is discoloured to yellow and becoming a stable molecule, depending on the number of electrons uptaken [5]. The aim of this study is the synthesis and physicochemical characterization of ortho and para hydroxychalcones containing the 2-arylthiazole moiety and flavonoid derivatives obtained by cyclization and oxidative cyclization, in order to evaluate in vitro their antioxidant potential.

\section{Materials and Methods}

\section{Chemistry}

The necessary reagents for the synthesis of the compounds were purchased from Sigma Aldrich (Germany) and the solvents were purchased from Chemical Company (Romania).

The ${ }^{1} \mathrm{H}$ NMR and ${ }^{13} \mathrm{C}$ NMR spectra were recorded in $\mathrm{CDCl}_{3}$ or DMSO- $\mathrm{D}_{6}$ solution on a Bruker Avance DPX-300 spectrometer operating at $600 \mathrm{MHz}$ and respectively $150 \mathrm{MHz}$. Chemical shifts on the $\delta$ scale are expressed in ppm values from TMS as internal standard. The following abbreviations are used in order to indicate the peak patterns: s-singlet, d-doublet, dd-double doublet, br s-broad singlet.

Mass spectra were recorded on Agilent 1100 Ion Trap mass spectrometer operating at $70 \mathrm{eV}$.

The FT-IR analysis was performed on a Jasco FT/IR 470 Plus spectrometer by using the Spectra Manager software. The solid sample was introduced in the ATR (attenuated total reflection) device's slot and the IR spectra were recorded between 4000 and $400 \mathrm{~cm}^{-1}$ wavelengths at $4 \mathrm{~cm}^{-1}$ resolution.

Thin layer chromatography (TLC) was carried out using Merck Kieselgel 60F254 sheets. Spots were visualized in UV light. Preparative chromatographic separations were performed using column chromatography on Merck Kieselgel $60 \AA$ (63 - $200 \mu \mathrm{m})$.

Melting points were determined on open glass capillaries using an Electrothermal IA 9000 digital apparatus (Bibby Scientific Limited, Staffordshire, UK). Synthesis of thiazole hydroxychalcones $\mathbf{3 a - h}$ 2-Arylthiazole-4-carbaldehyde 1a-h $(1 \mathrm{mmol})$ was dissolved in ethanol $(2.5 \mathrm{~mL})$. The acetophenone was added in an equimolar amount $(1 \mathrm{mmol}, 0.150 \mathrm{~g}$ ortho/ para hydroxyacetophenone). The obtained solution was cooled and treated with an aqueous solution of $50 \% \mathrm{KOH}(0.2 \mathrm{~mL}, 0.179 \mathrm{mmols} \mathrm{KOH})$. The reaction 
FARMACIA, 2018, Vol. 66, 4

mixture was stirred at room temperature for 23 hours. After the completion of reaction (monitored by TLC, eluent petroleum ether:ethyl acetate or dichloromethane:acetone, as indicated for each individual compound, in the Results and Discussions section), the reaction mixture was poured into ice and acidified with glacial acetic acid. The formed precipitate was filtered, dried and purified by recrystallization or column chromatography, using as eluent different solvent mixtures, as indicated for each individual compound, in the Results and Discussions section. Synthesis of thiazole flavanones 4 a-d

Method 1: an ethanolic solution of ortho hydroxychalcone $3 \mathbf{e}-\mathbf{h}$ ( $1 \mathrm{mmol}$ chalcone and $5 \mathrm{~mL}$ of ethanol) was treated with $0.8 \mathrm{~mL}$ concentrated $\mathrm{H}_{2} \mathrm{SO}_{4}$ and refluxed at $100^{\circ} \mathrm{C}$. The reaction was monitored by TLC using as eluent a mixture of petroleum ether:ethyl acetate $9 / 1$ or $6 / 1 \mathrm{v} / \mathrm{v}$. After completion of the reaction (checked by TLC after 6 hours, 12 hours and 18 hours), the solvent was evaporated under reduced pressure. The obtained flavanone was purified by column chromatography using as eluent a mixture of petroleum ether:ethyl acetate $9 / 1$ or $6 / 1 \mathrm{v} / \mathrm{v}$.

Method 2: a mixture of ortho hydroxychalcone $\mathbf{3 e - h}$ $(1 \mathrm{mmol})$ with sodium acetate $(6 \mathrm{mmols}, 500 \mathrm{mg})$ in ethanol $(5 \mathrm{~mL})$ and three drops of water was refluxed at $100^{\circ} \mathrm{C}$, for 48 hours. The reaction was monitored by TLC after every 8 hours. The obtained flavanone was extracted with ethyl acetate and purified by column chromatography using as eluent a mixture of petroleum ether - ethyl acetate.

Method 3: a solution of ortho hydroxychalcone 3e-h $(1 \mathrm{mmol})$ in glacial acetic acid $(5 \mathrm{~mL})$ was refluxed for 72 hours. The reaction was monitored by TLC after every 8 hours, using as eluent a mixture of petroleum ether:ethyl acetate $9 / 1 \mathrm{v} / \mathrm{v}$. The obtained reaction mixture was poured into ice. The formed precipitate was filtered, dried and purified by column chromatography using as eluent a mixture of petroleum ether:ethyl acetate $9 / 1 \mathrm{v} / \mathrm{v}$.

\section{Synthesis of thiazole flavones $5 \mathbf{a}$-d}

To a solution of ortho hydroxychalcone $3 \mathbf{e}-\mathbf{h}$ (1 mmol) dissolved in dimethyl sulfoxide $(5 \mathrm{~mL}) \mathrm{I}_{2}$ was added $(1 \mathrm{mmol}, 254 \mathrm{mg})$. The reaction mixture was refluxed at $160^{\circ} \mathrm{C}$ for $3-4$ hours. The reaction was monitored by TLC using a mixture of petroleum ether and ethyl acetate in different volume ratios, as indicated for each individual compound. After completion of the reaction, the excess of iodine was quenched with $20 \% \mathrm{Na}_{2} \mathrm{~S}_{2} \mathrm{O}_{3}$ aqueous solution for 30 minutes. The obtained flavone was extracted with ethyl acetate and purified by column chromatography using as eluent a mixture of petroleum ether - ethyl acetate in different volume ratios, as indicated for each individual compound, in the Results and discussions section.

Evaluation of the antioxidant activity

The spectrophotometric measurements of the antioxidant activity were performed using a V-530 Jasco spectrophotometer, at $517 \mathrm{~nm}$, in methanol or dichloromethane as solvent.

The obtained thiazole chalcones $\mathbf{3 a - h}$, flavanones 4a-d and flavones 5a-d were evaluated for their antioxidant activity in vitro, by applying the DPPH free radical scavenging method. The solutions were prepared in methanol $(0.085 \mu \mathrm{mol} / \mathrm{mL}$ for compounds 3a-d) or in dichloromethane $(0.06 \mu \mathrm{mol} / \mathrm{mL}$ for compounds 3e-h, 4a-d, 5a-d). An amount of $4 \mathrm{~mL}$ of the total reaction mixture (compound $+2 \mathrm{~mL}$ methanol $/ 2 \mathrm{~mL}$ dichloromethane $+2 \mathrm{~mL}$ DPPH solution $10 \mathrm{mg} / 100 \mathrm{~mL}$ solvent) were allowed to react at $40^{\circ} \mathrm{C}$ for 30 minutes. The absorbance values were spectrophotometrically measured at $517 \mathrm{~nm}$ for three times, for each compound, and the average value of the three determinations was converted into a percentage of antioxidant activity. For every compound we determined two percentage values of the antioxidant activity. The standards used in the antioxidant activity were ascorbic acid and quercetin.

\section{Results and Discussion}

Synthesis of thiazole aldehydes

Thiazole aldehydes 1a-d were synthesized as previously described in the literature [22]. The four thiazole aldehydes obtained were purified by column chromatography, using as eluent a mixture of petroleum ether:ethyl acetate $=4 / 1 \mathrm{v} / \mathrm{v}$ (Figure 1$)$. The global yields of the thiazole aldehydes synthesis ranged from $47 \%$ to $54 \%$.

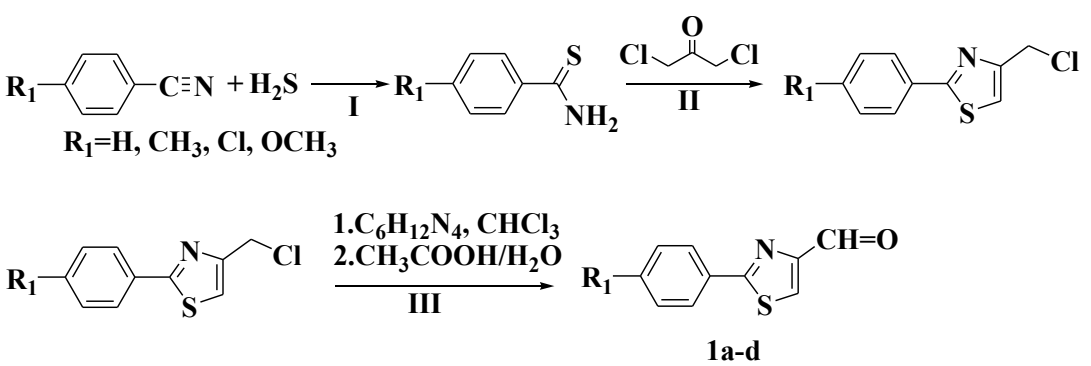

Figure 1.

Synthesis of thiazole aldehydes 1a-d; reaction conditions: I. ethanol, triethylamine, room temperature (r.t.), 48 h; II. acetone, r.t., 24 h; III. 1. urotropine, chloroform, water bath, 1.5 h, 2. urotropine, 50\% acetic acid, reflux, 1 h. 
FARMACIA, 2018, Vol. 66, 4

Synthesis and characterization of new thiazole hydroxychalcones

The synthesis of thiazole hydroxychalcones 3a-h (Table I) was performed by Claisen-Schmidt condensation [14, 18], starting from equimolar amounts of the previously obtained thiazole aldehydes 1a-d and the acetophenones substituted with a hydroxyl group in ortho or para position (Figure 2). The reaction was catalysed by potassium hydroxide [14]. The influence of the nature of the substituents in the two units (aldehyde and acetophenone) were studied for the reaction course. It was found that the reaction rate is neither influenced by the nature of the substituents grafted on the thiazole aldehyde, nor by the position of the hydroxyl group of the acetophenone. For the eight chalcones synthesized, the reaction time was about 23 hours. Chalcones substituted with a hydroxyl group in the ortho position of acetophenone were used for the synthesis of flavones and flavanones.

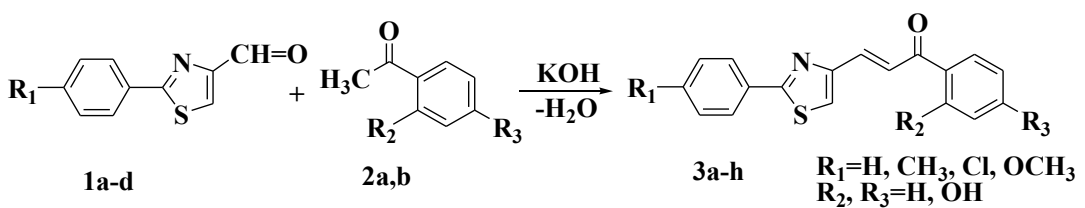

Figure 2.

Synthesis of thiazole ortho/para hydroxychalcones; reaction conditions: 50\% KOH/ethanol, r.t., $23 \mathrm{~h}$

Table I

The reaction yields and chemical structures of the synthesized thiazole hydroxychalcones 3a-h

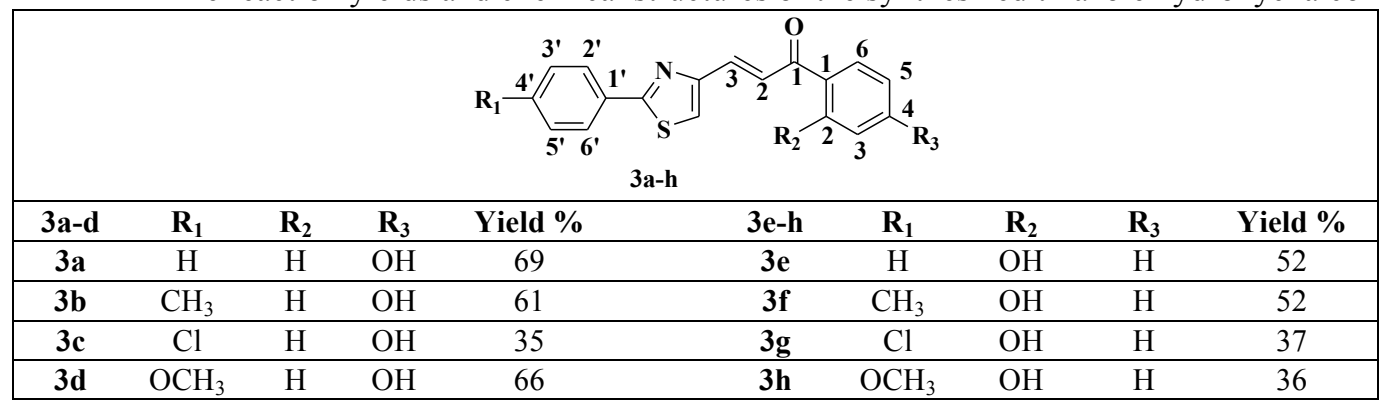

The synthesized thiazole chalcones were purified by recrystallization or column chromatography and characterized by ${ }^{1} \mathrm{H}$ NMR, ${ }^{13} \mathrm{C}$ NMR, IR and MS methods. The mass spectra revealed the corresponding molecular peaks.

In the ${ }^{1} \mathrm{H}$ NMR spectra of thiazole chalcones, all signals corresponding to the aromatic protons are appearing in the aromatic region at chemical shifts between 6.91 and $8.09 \mathrm{ppm}$. The proton located in the $5^{\text {th }}$ position of the thiazole ring appears as a singlet at chemical shifts between 7.23 and $8.27 \mathrm{ppm}$. The vinylic protons from the propenone chain are appearing as a doublet (d) or doublet of doublets (dd) at chemical shifts between 7.67 and 8.14 ppm. In all cases, the vinylic protons located in the $3^{\text {rd }}$ position of the propenone chain are more deshielded (7.69 - 7.84 ppm). The high coupling constants $(J=14.9-15.2 \mathrm{~Hz})$ for the vinylic protons are indicating that the chalcones 3a-h were obtained with $E$ configuration [26].

In the ${ }^{13} \mathrm{C}$ NMR spectra of thiazole chalcones, all signals corresponding to the aromatic carbons are present in the spectra $(115.55-167.85 \mathrm{ppm})$. The characteristic carbonylic signal appears at chemical shifts of 187.22 - $194.42 \mathrm{ppm}$. The vinylic carbon from the $3^{\text {rd }}$ position of the propenone chain appear at 130.06 - $133.21 \mathrm{ppm}$, being more deshielded than the vinylic carbon from the $2^{\text {nd }}$ position of the propenone chain, the latter having chemical shifts between 120.24 and $123.73 \mathrm{ppm}$. In the thiazole ring, the most deshielded carbon is located in the $2^{\text {nd }}$ position, appearing at chemical shifts between 163.7 and 168.0 ppm. The carbon located in the $5^{\text {th }}$ position of the thiazole ring appears at $123.49-125.40 \mathrm{ppm}$.

In the IR spectra of thiazole chalcones $\mathbf{3 a}-\mathbf{h}$, the range of wave numbers for aromatic $\mathrm{C}-\mathrm{H}$ stretching band is $3097-3092 \mathrm{~cm}^{-1}$, and for carbonyl bands (ketone type) is $1655-1646 \mathrm{~cm}^{-1}$, excepting compound $\mathbf{3 g}$ $\left(1579 \mathrm{~cm}^{-1}\right)$ and compound $\mathbf{3 h}\left(1576 \mathrm{~cm}^{-1}\right)$.

Synthesis and characterization of new thiazole flavanones

The synthesis of thiazole flavanones (4a-d, Table II) was performed by the cyclization of ortho hydroxychalcones. Different reaction conditions were tested for the efficient production of the target compounds: in ethanol as solvent, with concentrated sulfuric acid at reflux [4], in ethanol with sodium acetate at reflux [19] and in glacial acetic acid, at reflux [7]. The reaction time and yield for each cyclization method are mentioned in Table II.

It was found that the cyclization of ortho hydroxychalcones in ethanol in the presence of concentrated sulfuric acid at $100^{\circ} \mathrm{C}$ is the most beneficial for the 
reaction course, in terms of efficiency and reaction rate (Table II). It has been observed that a rise in temperature favours some secondary reactions, which results in a significant decrease of the yield.

The cyclization of ortho hydroxychalcones in glacial acetic acid at reflux proved to be unfavourable for the synthesis of flavanones, because the reaction occurred

with low rate and the product was obtained with low yield $(22 \%)$.

The use of sodium acetate in ethanol at reflux afforded the desired product with moderate yield (41\%), but the reaction rate was low. Based on these results, the synthesis of the thiazole flavanones was performed by the most efficient method - treatment with concentrated sulfuric acid, in ethanol, at $100^{\circ} \mathrm{C}$.

Table II

Synthesis, reaction time and yields of the thiazole flavanones 4a-d

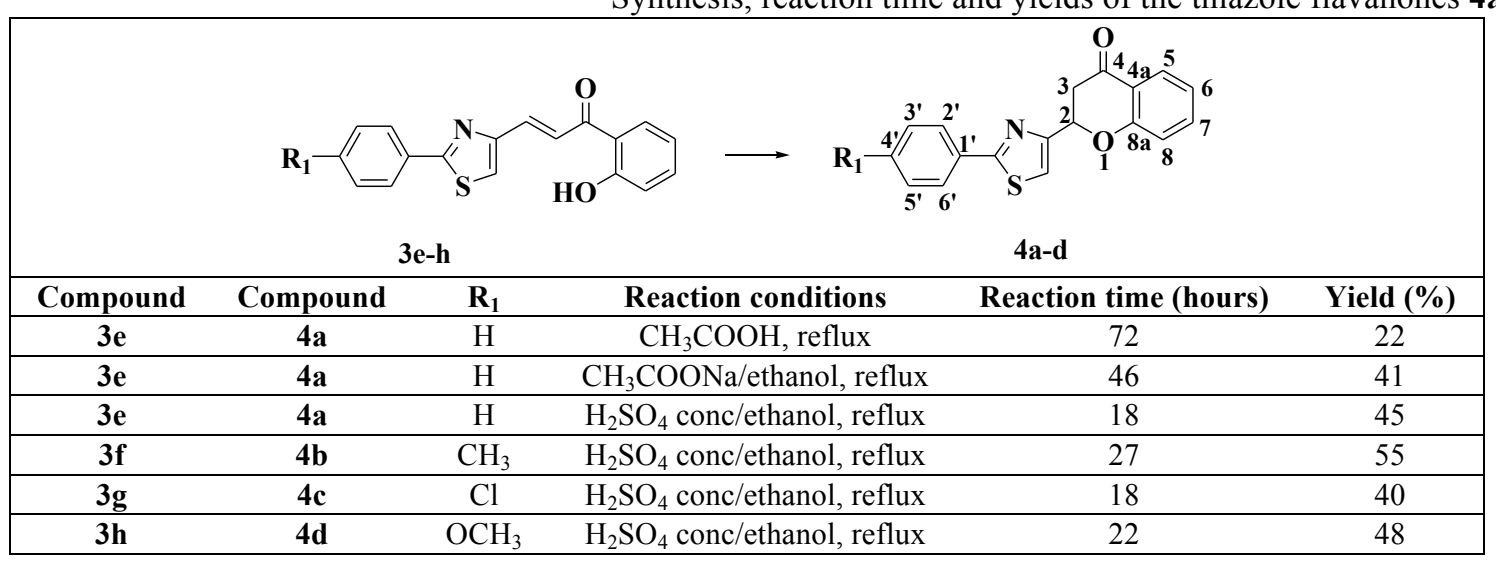

The obtained thiazole flavanones were purified by column chromatography and characterized by ${ }^{1} \mathrm{H}$ $\mathrm{NMR},{ }^{13} \mathrm{C} \mathrm{NMR}$, IR and MS analysis. In the mass spectra of thiazole flavanones 4a-d, the molecular peaks confirm that the desired products were formed. The cyclization of chalcones to flavanones determined characteristic spectral changes. In the ${ }^{1} \mathrm{H}$ NMR spectra of flavanones $\mathbf{4 a - d}$, two characteristic signals corresponding to the protons located in the $2^{\text {nd }}$ and $3^{\text {rd }}$ positions of the chroman-4-one ring are present in the aliphatic area. The protons located in the $2^{\text {nd }}$ position of the chroman-4-one are appearing as doublet of doublets (dd) at chemical shifts between 3.18 and $3.32 \mathrm{ppm}$. The two aliphatic protons from the $3^{\text {rd }}$ position of the chroman-4-one ring are appearing as two distinct dd at $5.71-5.73 \mathrm{ppm}$. The signals of the vinylic protons are not present in the ${ }^{1} \mathrm{H}$ NMR spectra, indicating that the cyclisation of chalcones occurred. In the ${ }^{13} \mathrm{C}$ NMR spectra, the formation of the chroman4-one ring was confirmed by the presence of two signals in the aliphatic area corresponding to the $\mathrm{sp}^{3}$ carbons from the $2^{\text {nd }}(75.98-76.10 \mathrm{ppm})$ and $3^{\text {rd }}$ (42.66 - $42.87 \mathrm{ppm}$ ) positions of the chroman-4-one. A characteristic carbonylic signal at $191.60-191.77$ ppm indicates the presence of the chroman-4-one $\mathrm{C}=\mathrm{O}$ group.

In the IR spectra of the thiazole flavanones $4 \mathbf{a}-\mathbf{d}$, the wave number for aliphatic $\mathrm{C}-\mathrm{H}$ stretching is exactly $2918.73 \mathrm{~cm}^{-1}$ for all flavanones, the wavenumber for aromatic $\mathrm{C}-\mathrm{H}$ stretching is in the range 3100.97 $3100.01 \mathrm{~cm}^{-1}$. The carbonyl group of chroman-4-one has the stretching wave number between 1686.44 $1686.37 \mathrm{~cm}^{-1}$.
Synthesis and characterization of new thiazole flavones Thiazole flavones 5a-d were obtained by oxidative cyclization of ortho hydroxychalcones, using iodine in dimethylsulfoxide (Table III). Chimenti and collaborators performed the oxidative cyclization at $130^{\circ} \mathrm{C}$ [10]. In our case, it was found that the oxidative cyclisation with iodine in dimethylsulfoxide occurred at $160^{\circ} \mathrm{C}$ with higher reaction rate. Therefore, this temperature was used for the synthesis of all thiazole derived flavones 5a-d. The obtained products were purified by column chromatography and characterized by ${ }^{1} \mathrm{H} \mathrm{NMR},{ }^{13} \mathrm{C} \mathrm{NMR}$, IR and MS spectral methods.

In the mass spectra of flavones 5a-d, the presence of the molecular peaks are revealing the formation of the desired products. In the ${ }^{1} \mathrm{H}$ NMR spectra, the vinylic signals are absent, thus confirming that the cyclization of chalcones occurred. A characteristic singlet (s) at $7.31-7.40 \mathrm{ppm}$, corresponding to the proton from the $3^{\text {rd }}$ position, indicates the formation of the chromen-4-one moiety.

In the ${ }^{13} \mathrm{C} N M R$ spectra, the formation of the chromen4-one ring system was confirmed by the presence of two signals corresponding to the carbon atoms from the $2^{\text {nd }}(156.19-156.21 \mathrm{ppm})$ and $3^{\text {rd }}(108.40$ $108.75 \mathrm{ppm}$ ) position of the chromen-4-one moiety. In the IR spectra of the thiazole derived flavones 5a-d, the wave number for aliphatic $\mathrm{C}-\mathrm{H}$ stretching is in the range $2923.56-2920.66 \mathrm{~cm}^{-1}$, the wavenumber for aromatic $\mathrm{C}-\mathrm{H}$ stretching is in the range 3142.44 $3063.37 \mathrm{~cm}^{-1}$. The carbonyl group of chromen-4-one has the stretching wavenumber between 1607.38 and $1606.41 \mathrm{~cm}^{-1}$. 
Synthesis, reaction time and yields of thiazole flavones 5a-d

\begin{tabular}{|c|c|c|c|c|}
\hline \multicolumn{3}{|c|}{ 3e-h } & \multicolumn{2}{|l|}{ 5a-d } \\
\hline Compound & Compound & $\mathbf{R}_{1}$ & Reaction time (hours) & Yield (\%) \\
\hline $3 \mathrm{e}$ & $5 \mathbf{a}$ & $\mathrm{H}$ & 3 & 45 \\
\hline 3f & $5 \mathbf{b}$ & $\mathrm{CH}_{3}$ & 3.5 & 55 \\
\hline $3 g$ & $5 c$ & $\mathrm{Cl}$ & 4 & 39 \\
\hline $3 \mathbf{h}$ & 5d & $\mathrm{OCH}_{3}$ & 4 & 32 \\
\hline
\end{tabular}

(E)-1-(4-Hydroxyphenyl)-3-(2-phenylthiazol-4-yl)prop2-en-1-one (3a) [3]: Pale-yellow powder; purified by recrystallization from dimethyl formamide; yield: 69\%; mp: $211-214.7^{\circ} \mathrm{C} ; R_{f}=0.42$ (eluent: petroleum ether:ethyl acetate $=9: 1 \mathrm{v} / \mathrm{v})$. IR: $\bar{v}\left(\mathrm{~cm}^{-1}\right): 3092.3$ (C-H arom), $1595.81(\mathrm{C}=\mathrm{O}) ;{ }^{1} \mathrm{H}$ NMR $(600 \mathrm{MHz}$, DMSO) $\delta 10.47$ (br s, OH), $8.25(\mathrm{~s}, 1 \mathrm{H}, \mathrm{CH}-5$ thiazole), 8.10 - 8.04 (m, 2H, CH-2', CH-6' Phe), 8.02 (d, $J=8.7 \mathrm{~Hz}, 2 \mathrm{H}, \mathrm{CH}-2, \mathrm{CH}-6), 7.98$ (d, $J=15.2 \mathrm{~Hz}$, $1 \mathrm{H}, \mathrm{CH}-3$ vinyl), 7.71 (d, $J=15.1 \mathrm{~Hz}, 1 \mathrm{H}, \mathrm{CH}-2$ vinyl), 7.58 - 7.52 (m, 3H, CH-3', CH-4', CH-5' Phe), $6.93(\mathrm{~d}, J=8.7 \mathrm{~Hz}, 2 \mathrm{H}, \mathrm{CH}-3, \mathrm{CH}-5) ;{ }^{13} \mathrm{C} \mathrm{NMR}$ $(151 \mathrm{MHz}, \mathrm{DMSO}) \delta 187.26(\mathrm{C}, \mathrm{C}=\mathrm{O}), 167.76(\mathrm{C}$, $\mathrm{C}-2$ thiazole), 162.32 (C, C4-OH), 152.71 (C, C-4 thiazole), 134.97 (C, C-1' Phe), 132.59 (CH, C-3 vinyl), 131.07 (CH, C-4'Phe), 130.81 (CH, C-2, C-6), 129.32 (C, C-1), 128.99 (C, C-3', C-5' Phe), 126.56 (CH, C-2', C-6' Phe), 124.25 (CH, C-5 thiazole), 123.59 (CH, C-2 vinyl), 115.55 (CH, C-3, C-5); MS: m/z 308.8 $\left[\mathrm{M}+\mathrm{H}^{+}\right]$(calculated for $\left.\mathrm{C}_{18} \mathrm{H}_{14} \mathrm{NO}_{2} \mathrm{~S}^{+}: 308.07\right)$.

(E)-1-(4-Hydroxyphenyl)-3-(2-(p-tolyl)thiazol-4-yl)prop-2-en-1-one (3b) [3]: White powder; purified by recrystallization from ethanol and water; yield: $61 \%$; mp: $192.2-194.5^{\circ} \mathrm{C} ; \mathrm{R}_{f}=0.43$ (eluent: petroleum ether:ethyl acetate $=7: 3 \mathrm{v} / \mathrm{v})$. IR: $\bar{v}\left(\mathrm{~cm}^{-1}\right): 3095.19$ (C-H arom), $1577.49(\mathrm{C}=\mathrm{O}) ;{ }^{1} \mathrm{H}$ NMR $(600 \mathrm{MHz}$, DMSO) $\delta 10.51$ (br s, OH), $8.19(\mathrm{~s}, 1 \mathrm{H}, \mathrm{CH} 5-$ thiazole), 8.01 (d, $J=8.7 \mathrm{~Hz}, 2 \mathrm{H}, \mathrm{CH}-2, \mathrm{CH}-6)$, 7.95 (d, $J=15.0 \mathrm{~Hz}, 1 \mathrm{H}, \mathrm{CH}-3$ vinyl, overlapped with 7.95 (d, $J=8.2 \mathrm{~Hz}, 2 \mathrm{H}, \mathrm{CH}-2$ ', CH-6'), 7.69 (d, $J=15.1 \mathrm{~Hz}, 1 \mathrm{H}, \mathrm{CH}-2$ vinyl), 7.35 (d, $J=8.0 \mathrm{~Hz}$, 2H, CH-3', CH-5'), 6.92 (d, $J=8.7 \mathrm{~Hz}, 2 \mathrm{H}, \mathrm{CH}-3$, $\mathrm{CH}-5), 2.38\left(\mathrm{~s}, 3 \mathrm{H}, \mathrm{CH}_{3}\right) ;{ }^{13} \mathrm{C}$ NMR $(151 \mathrm{MHz}$, DMSO) $\delta 187.41(\mathrm{C}, \mathrm{C}=\mathrm{O}), 168.00(\mathrm{C}, \mathrm{C}-2$ thiazole $)$, 162.37 (C, C4-OH), 152.65 (C, C-4 thiazole), 140.86 (C, C-4'), 135.12 (C, C-1'), 131.15 (CH, C-2, C-6), 130.06 (CH, C-3 vinyl), 129.93 (CH, C-3', C-5'), 129.08 (C, C-1), 126.57 (CH, C-2', C-6'), 123.96 (CH, C-5 thiazole), 123.53 (CH, C-2 vinyl), 115.64 (CH, C-3, C-5), $21.08\left(\mathrm{CH}_{3}\right)$; MS: $m / z 322.6\left[\mathrm{M}+\mathrm{H}^{+}\right]$ (calculated for $\left.\mathrm{C}_{19} \mathrm{H}_{16} \mathrm{NO}_{2} \mathrm{~S}^{+}: 322.09\right)$.

(E)-3-(2-(4-Chlorophenyl)thiazol-4-yl)-1-(4-hydroxyphenyl)prop-2-en-1-one (3c) [3]: Pale-yellow powder; purified by recrystallization from dimethyl formamide; yield: $35 \%$; mp: $201.7-204.9^{\circ} \mathrm{C} ; R_{f}=0.55$ (eluent: dichloromethane:acetone $=9: 1 \mathrm{v} / \mathrm{v})$. IR: $\bar{v}\left(\mathrm{~cm}^{-1}\right)$ : 3093.26 (C-H arom), $1589.06(\mathrm{C}=\mathrm{O}) ;{ }^{1} \mathrm{H}$ NMR (600 MHz, DMSO) $\delta 10.48(\mathrm{~s}, 1 \mathrm{H}, \mathrm{OH}), 8.27$ (s, $1 \mathrm{H}, \mathrm{CH}-5$ thiazole), 8.09 (d, $J=8.5 \mathrm{~Hz}, 2 \mathrm{H}, \mathrm{CH}-2$ ', CH-6'), 8.02 (d, $J=8.7 \mathrm{~Hz}, 2 \mathrm{H}, \mathrm{CH}-2, \mathrm{CH}-6), 7.97$ (d, $J=15.2 \mathrm{~Hz}, 1 \mathrm{H}, \mathrm{CH}-3$ vinyl), $7.71(\mathrm{~d}, J=15.2 \mathrm{~Hz}$, $1 \mathrm{H}, \mathrm{CH}-2$ vinyl), 7.61 (d, $J=8.5 \mathrm{~Hz}, 2 \mathrm{H}, \mathrm{CH}-3$ ', $\mathrm{CH}-5$ '), 6.93 (d, $J=8.7 \mathrm{~Hz}, 2 \mathrm{H}, \mathrm{CH}-3, \mathrm{CH}-5) ;{ }^{13} \mathrm{C}$ NMR (151 MHz, DMSO) $\delta 187.22(\mathrm{C}, \mathrm{C}=\mathrm{O}), 166.42$ (C, C-2 thiazole), 162.33 (C, C-4-OH), 152.79 (C, C-4 thiazole), 135.35 (C, C-4'), 134.82 (C, C-1'), $131.43(\mathrm{CH}, \mathrm{C}-3$ vinyl), 131.07 (CH, C-2, C-6), 129.37 (CH, C-3', C-5'), 128.97 (C, C-1), 128.26 (CH, C-2', C-6'), 124.61 (CH, C-5 thiazole), 123.73 (CH, C-2 vinyl), 115.55 (CH, C-3, C-5); MS: $m / z$ $342.4\left[\mathrm{M}+\mathrm{H}^{+}\right]$(calculated for $\left.\mathrm{C}_{18} \mathrm{H}_{13} \mathrm{ClNO}_{2} \mathrm{~S}^{+}: 342.04\right)$. (E)-1-(4-Hydroxyphenyl)-3-(2-(4-methoxyphenyl)thiazol-4-yl)prop-2-en-1-one (3d): Pale-yellow powder; purified by recrystallization from dimethyl formamide; yield: $66 \%$; mp: $117.4-121.3^{\circ} \mathrm{C} ; R_{f}=0.45$ (eluent: petroleum ether:ethyl acetate $=9 / 1 \mathrm{v} / \mathrm{v})$. IR: $\bar{v}\left(\mathrm{~cm}^{1}\right)$ : 3092.3 (CH arom), $1588.09(\mathrm{C}=\mathrm{O}) ;{ }^{1} \mathrm{H}$ NMR (600 $\mathrm{MHz}, \mathrm{DMSO}) \delta 10.41(\mathrm{~s}, 1 \mathrm{H}, \mathrm{OH}), 8.12(\mathrm{~s}, 1 \mathrm{H}$, $\mathrm{CH}-5$ thiazole), 8.03 - 7.96 (m, 4H, CH-2', CH-6', $\mathrm{CH}-2, \mathrm{CH}-6), 7.93$ (d, $J=15.1 \mathrm{~Hz}, 1 \mathrm{H}, \mathrm{CH}-3$ vinyl), 7.67 (d, $J=15.1 \mathrm{~Hz}, 1 \mathrm{H}, \mathrm{CH}-2$ vinyl), 7.08 (d, $J=8.5$ Hz, 2H, CH-3', CH-5'), 6.91 (d, J=6.9 Hz, 2H, CH-3, $\mathrm{CH}-5), 3.84\left(\mathrm{~s}, 3 \mathrm{H}, \mathrm{OCH}_{3}\right) ;{ }^{13} \mathrm{C} \mathrm{NMR}(151 \mathrm{MHz}$, DMSO) $\delta 187.26(\mathrm{C}, \mathrm{C}=\mathrm{O}), 167.61(\mathrm{C}, \mathrm{C}-2$ thiazole $)$, 162.25 (C, C-4 OH), 161.25 (C, C-4'), 152.50 (C, C-4 thiazole), 135.01 (C, C-1'), 130.95 ( $\mathrm{CH}, \mathrm{C}-2$, C-6), 130.91 (CH, C-3 vinyl) 129.01 (C, C-1), 128.14 (CH, C-2', C-6'), 125.40 (CH, C-5 thiazole), 123.32 (CH, C-2 vinyl), $115.48(\mathrm{CH}, \mathrm{C}-3, \mathrm{C}-5), 114.55(\mathrm{CH}$, C-3', C-5'), $55.40\left(\mathrm{CH}_{3}, \mathrm{OCH}_{3}\right)$; MS: $\mathrm{m} / \mathrm{z} 338.4$ $\left[\mathrm{M}+\mathrm{H}^{+}\right]$(calculated for $\mathrm{C}_{19} \mathrm{H}_{16} \mathrm{NO}_{3} \mathrm{~S}^{+}: 337.08$ ).

(E)-1-(2-Hydroxyphenyl)-3-(2-phenylthiazol-4-yl)prop-2-en-1-one (3e) [3]: Yellow powder; purified by column chromatography (eluent: petroleum ether:ethyl acetate $=9 / 1 \mathrm{v} / \mathrm{v})$; yield: $52 \%$; mp: $139.3-141.4^{\circ} \mathrm{C}$; $R_{f}=0.48$ (eluent: petroleum ether:ethyl acetate $=9 / 1$ v/v). IR: $\bar{v}\left(\mathrm{~cm}^{-1}\right): 3097.12(\mathrm{CH}$ arom $), 1576.52(\mathrm{C}=\mathrm{O})$; ${ }^{1} \mathrm{H}$ NMR $\left(600 \mathrm{MHz}, \mathrm{CDCl}_{3}\right) \delta 12.87$ (s, 1H, OH), 
FARMACIA, 2018, Vol. 66, 4

$8.13(\mathrm{~d}, J=14.9 \mathrm{~Hz}, 1 \mathrm{H}, \mathrm{CH}-3$ vinyl), $8.07-8.03$ (m, 3H, CH-2', CH-6', CH-6), 7.84 (dd, $J=14.9$, $1.7 \mathrm{~Hz}, 1 \mathrm{H}, \mathrm{CH}-2$ vinyl), 7.57 (s, $1 \mathrm{H}, \mathrm{CH}-5$ thiazole), 7.54 - 7.48 (m, 4H, CH-4, CH-3', CH-4', CH-5'), 7.04 (dd, $J=8.3,0.8 \mathrm{~Hz}, 1 \mathrm{H}, \mathrm{CH}-3), 7.00-6.96$ (m, $1 \mathrm{H}, \mathrm{CH}-5) ;{ }^{13} \mathrm{C}$ NMR $\left(151 \mathrm{MHz}, \mathrm{CDCl}_{3}\right) \delta 194.39$ (C, C=O), 169.24 (C, C-2 thiazole), 163.74 (C, C-2), 153.12 (C, C-4 thiazole), 136.65 (CH, C-4), 136.60 (C, C-1'), 133.21 (CH, C-3 vinyl), 130.89 (CH, C-4'), 130.28 (CH, C-6), 129.22 (CH, C-3', C-5'), 127.07 (CH, C-2', C-6'), 123.77 (CH, C-5 thiazole), 122.88 (C, C-1), 120.28 (CH, C-2 vinyl), $119.10(\mathrm{CH}, \mathrm{C}-5)$, 118.65 (CH, C-3); MS: $m / z$ 308.2 [M+H $\left.{ }^{+}\right]$(calculated for $\mathrm{C}_{18} \mathrm{H}_{14} \mathrm{NO}_{2} \mathrm{~S}^{+}$: 308.07).

(E)-1-(2-Hydroxyphenyl)-3-(2-(p-tolyl)thiazol-4-yl)prop-2-en-1-one (3f) [3]: Yellow powder; purified by column chromatography (eluent: petroleum ether:ethyl acetate $=9 / 1 \mathrm{v} / \mathrm{v}$ ); yield: $52 \%$; mp: $101.7-103.9^{\circ} \mathrm{C}$; $R_{f}=0.52$ (eluent: petroleum ether:ethyl acetate $=9 / 1$ v/v). IR: $\bar{v}\left(\mathrm{~cm}^{-1}\right): 3100.01(\mathrm{CH}$ arom), $2930.31(\mathrm{C}-\mathrm{H}$ aliphatic), $1577.49(\mathrm{C}=\mathrm{O}) ;{ }^{1} \mathrm{H}$ NMR $(600 \mathrm{MHz}$, $\left.\mathrm{CDCl}_{3}\right) \delta 12.88($ br s, $1 \mathrm{H}, \mathrm{OH}), 8.11(\mathrm{~d}, J=14.9 \mathrm{~Hz}$, $1 \mathrm{H}, \mathrm{CH}-3$ vinyl), 8.05 (d, $J=8.0 \mathrm{~Hz}, 1 \mathrm{H}, \mathrm{CH}-6), 7.93$ (d, $J=8.1 \mathrm{~Hz}, 2 \mathrm{H}, \mathrm{CH}-2$ ', CH-6'), 7.82 (dd, $J=14.9$, $1.6 \mathrm{~Hz}, 1 \mathrm{H}, \mathrm{CH}-2$ vinyl), 7.53 (s, $1 \mathrm{H}, \mathrm{CH}-5$ thiazole) overlapped with $7.53-7.50$ (m, 1H, CH-4), 7.29 (d, $J=7.9 \mathrm{~Hz}, 2 \mathrm{H}, \mathrm{CH}-3$ ', CH-5'), 7.03 (dd, $J=8.3$, $0.7 \mathrm{~Hz}, 1 \mathrm{H}, \mathrm{CH}-3), 7.00-6.95$ (m, 1H, CH-5), 2.43 (s, 3H, $\left.\mathrm{CH}_{3}\right) ;{ }^{13} \mathrm{C}$ NMR $\left(151 \mathrm{MHz}, \mathrm{CDCl}_{3}\right) \delta 194.42$ (C, C=O), 169.40 (C, C-2 thiazole), 163.73 (C, C-2), 153.00 (C, C-4 thiazole), 141.28 (C, C-4'), 136.77 (CH, C-4), 136.60 (C, C-1'), 130.58 (CH, C-3 vinyl), 130.27 (CH, C-6), 129.88 (CH, C-3', C-5'), 126.98 (CH, C-2', C-6'), 123.49 (CH, C-5 thiazole), 122.71 (C, C-1), 120.29 (CH, C-2 vinyl), 119.04 (CH, C-5), $118.63(\mathrm{CH}, \mathrm{C}-3), 21.65\left(\mathrm{CH}_{3}\right)$; MS: $m / z 322.4$ $\left[\mathrm{M}+\mathrm{H}^{+}\right]$(calculated for $\mathrm{C}_{19} \mathrm{H}_{16} \mathrm{NO}_{2} \mathrm{~S}^{+}: 322.09$ ).

(E)-3-(2-(4-Chlorophenyl)thiazol-4-yl)-1-(3-hydroxyphenyl)prop-2-en-1-one (3g) [3]: Yellow powder; purified by column chromatography (eluent: petroleum ether:ethyl acetate $=9 / 1 \mathrm{v} / \mathrm{v}$ ); yield: $37 \%$; mp: 157.8 $159.9^{\circ} \mathrm{C} ; R_{f}=0.45$ (eluent: petroleum ether:ethyl acetate $=9 / 1 \mathrm{v} / \mathrm{v})$. IR: $\bar{v}\left(\mathrm{~cm}^{-1}\right): 3101.94(\mathrm{CH}$ arom $)$, $1579.41(\mathrm{C}=\mathrm{O})$; ${ }^{1} \mathrm{H}$ NMR $\left(600 \mathrm{MHz}, \mathrm{CDCl}_{3}\right) \delta 12.84$ (s, $1 \mathrm{H}, \mathrm{OH}), 8.10$ (d, $J=14.9 \mathrm{~Hz}, 1 \mathrm{H}, \mathrm{CH}-3$ vinyl), 8.03 (d, $J=8.4 \mathrm{~Hz}, 1 \mathrm{H}, \mathrm{CH}-6), 8.00-7.96$ (m, 2H, CH-2', CH-6'), 7.82 (dd, $J=14.9,1.6 \mathrm{~Hz}, 1 \mathrm{H}, \mathrm{CH}-2$ vinyl), 7.57 (s, $1 \mathrm{H}, \mathrm{CH}-5$ thiazole), 7.52 (ddd, $J=8.5$, 7.3, 1.6 Hz, 1H, CH-4), 7.48 - 7.45 (m, 2H, CH-3', CH-5'), 7.04 (dd, $J=8.4,0.9 \mathrm{~Hz}, 1 \mathrm{H}, \mathrm{CH}-3), 7.00$ $6.95(\mathrm{~m}, 1 \mathrm{H}, \mathrm{CH}-5) ;{ }^{13} \mathrm{C} \mathrm{NMR}\left(151 \mathrm{MHz}, \mathrm{CDCl}_{3}\right) \delta$ 194.30 (C, $\mathrm{C}=\mathrm{O}), 167.85$ (C, C-2 thiazole), 163.75 (C, C-2), 153.25 (C, C-4 thiazole), 136.91 (C, C-4'), 136.70 (C, C-1'), 136.44 (CH, C-4), 131.69 (CH, C-3 vinyl), 130.24 (CH, C-6), 129.46 (CH, C-3', C-5'), 128.25 (CH, C-2', C-6'), 123.81 (CH, C-5 thiazole), 123.06 (C, C-1), 120.24 (CH, C-2 vinyl), 119.07 (CH,
C-5), 118.69 (CH, C-3); MS: $m / z 342.07\left[\mathrm{M}+\mathrm{H}^{+}\right]$ (calculated for $\left.\mathrm{C}_{18} \mathrm{H}_{13} \mathrm{ClNO}_{2} \mathrm{~S}^{+}: 342.04\right)$.

(E)-1-(3-Hydroxyphenyl)-3-(2-phenylthiazol-4-yl)prop-2-en-1-one $(\mathbf{3 h})$ : Yellow powder; purified by column chromatography (eluent: petroleum ether:ethyl acetate $=9 / 1 \mathrm{v} / \mathrm{v}$ ); yield: $36 \%$; mp: $123.4-126.6^{\circ} \mathrm{C}$; $R_{f}=0.37$ (eluent: petroleum ether:ethyl acetate $=9 / 1$ v/v). IR: $\bar{v}\left(\mathrm{~cm}^{-1}\right): 3091.33(\mathrm{CH}$ arom), $2931.27(\mathrm{C}-\mathrm{H}$ aliphatic), $1575.56(\mathrm{C}=\mathrm{O}) ;{ }^{1} \mathrm{H}$ NMR $(600 \mathrm{MHz}$, $\left.\mathrm{CDCl}_{3}\right) \delta 12.83(\mathrm{~s}, 1 \mathrm{H}, \mathrm{OH}), 8.14(\mathrm{~d}, J=14.9 \mathrm{~Hz}$, $1 \mathrm{H}, \mathrm{CH}-3$ vinyl), $8.05(\mathrm{~d}, J=8.0 \mathrm{~Hz}, 1 \mathrm{H}, \mathrm{CH}-6)$, 8.00 (d, $J=8.4 \mathrm{~Hz}, 2 \mathrm{H}, \mathrm{CH}-2$ ', CH-6'), 7.82 (d, $J=14.9 \mathrm{~Hz}, 1 \mathrm{H}, \mathrm{CH}-2$ vinyl), 7.58 (s, 1H, CH-5 thiazole), 7.52 (tt, $J=10.9,5.4 \mathrm{~Hz}, 1 \mathrm{H}, \mathrm{CH}-4), 7.46$ (d, $J=8.5 \mathrm{~Hz}, 2 \mathrm{H}, \mathrm{CH}-3$ ', CH-5'), 7.04 (d, $J=9.1$ $\mathrm{Hz}, 1 \mathrm{H}, \mathrm{CH}-3), 6.98$ (t, $J=7.6 \mathrm{~Hz}, 1 \mathrm{H}, \mathrm{CH}-5), 3.90$ (s, $\left.3 \mathrm{H}, \mathrm{OCH}_{3}\right) ;{ }^{13} \mathrm{C} \mathrm{NMR}\left(151 \mathrm{MHz}, \mathrm{CDCl}_{3}\right) \delta 194.28$ (C, $\mathrm{C}=\mathrm{O}), 167.99$ (C, C-2 thiazole), 163.76 (C, C-4'), 163.44 (C, C-2), 153.13 (C, C-4 thiazole), 136.72 (CH, C-4), 136.25 (C, C-1'), 131.53 (CH, C-3 vinyl), 130.26 (CH, C-6), 129.50 (CH, C-2', C-6'), 128.32 (CH, C-3', C-5'), 123.77 (CH, C-5 thiazole), 123.26 (C, C-1), 120.25 (CH, C-2 vinyl), 119.09 (CH, C-5), 118.69 (CH, C-3), $55.79\left(\mathrm{CH}_{3}, \mathrm{OCH}_{3}\right)$; MS: $m / z 338.2$ $\left[\mathrm{M}+\mathrm{H}^{+}\right]$(calculated for $\mathrm{C}_{19} \mathrm{H}_{16} \mathrm{NO}_{3} \mathrm{~S}^{+}: 338.09$ ).

2-(2-Phenylthiazol-4-yl)chroman-4-one (4a): White powder; purified by column chromatography (eluent: petroleum ether:ethyl acetate $=9 / 1 \mathrm{v} / \mathrm{v}$ ); yield: $45 \%$; mp: $108.2-111.8^{\circ} \mathrm{C} ; R_{f}=0.35$ (eluent: petroleum ether: ethyl acetate $=9 / 1 \mathrm{v} / \mathrm{v})$. IR: $\bar{v}\left(\mathrm{~cm}^{-1}\right): 3100.97(\mathrm{CH}$ arom), 2918.73 ( $\mathrm{CH}$ aliphatic), $1686.37(\mathrm{C}=\mathrm{O}) ;{ }^{1} \mathrm{H}$ NMR (600 MHz, $\left.\mathrm{CDCl}_{3}\right) \delta 8.00-7.89$ (m, 3H, CH-2', CH-6', CH-5 chroman-4-one), 7.52 (t, $J=8.1 \mathrm{~Hz}$, 1H, CH-7 chroman-4-one), 7.46-7.43 (m, 3H, CH-3', CH-4', CH-5'), 7.40 (s, 1H, CH-5 thiazole), 7.09 - 7.05 (m, 2H, CH-6, CH-8 chroman-4-one), 5.73 (dd, $J=11.8,3.3 \mathrm{~Hz}, 1 \mathrm{H}, \mathrm{CH}-2$ chroman-4-one), 3.32 (dd, $J=16.9,11.8 \mathrm{~Hz}, 1 \mathrm{H}, \mathrm{CH}-3$ chroman-4-one), 3.20 (dd, $J=17.0,3.4 \mathrm{~Hz}, 1 \mathrm{H}, \mathrm{CH}-3$ chroman-4one); ${ }^{13} \mathrm{C}$ NMR $\left(151 \mathrm{MHz}, \mathrm{CDCl}_{3}\right) \delta 191.75(\mathrm{C}$, $\mathrm{C}=\mathrm{O}), 169.16(\mathrm{C}, \mathrm{C}-2$ thiazole $), 161.11(\mathrm{C}, \mathrm{C}-8 \mathrm{a}$ chroman-4-one), 154.73 (C, C-4 thiazole), 136.30 (CH, C-5 thiazole), 133.42 (C, C-1'), $130.48(\mathrm{CH}$, C-7 chroman-4-one), 129.12 (CH, C-3', C-5'), 127.18 (C, C-4'), 126.78 (CH, C-2', C-6'), 121.87 (CH, C-5 chroman-4-one), 121.34 (CH, C-6 chroman-4-one), 118.25 (C, C-4a chroman-4-one), 116.30 (CH, C-8 chroman-4-one), 76.10 ( $\mathrm{CH}, \mathrm{C}-2$ chroman-4-one), $42.87\left(\mathrm{CH}_{2}, \mathrm{C}-3\right.$ chroman-4-one $)$; MS: $m / z 308.3$ $\left[\mathrm{M}+\mathrm{H}^{+}\right]$(calculated for $\mathrm{C}_{18} \mathrm{H}_{14} \mathrm{NO}_{2} \mathrm{~S}^{+}: 308.07$ ).

2-(2-(p-Tolyl)thiazol-4-yl)chroman-4-one (4b): White powder; purified by column chromatography (eluent: petroleum ether:ethyl acetate $=6 / 1 \mathrm{v} / \mathrm{v}$ ); yield: $55 \%$; mp: $124.6-128.1^{\circ} \mathrm{C} ; R_{f}=0.43$ (eluent: petroleum ether:ethyl acetate $=9 / 1 \mathrm{v} / \mathrm{v})$. IR: $\bar{v}\left(\mathrm{~cm}^{-1}\right): 3100.01$ ( $\mathrm{CH}$ arom), 2918.73 ( $\mathrm{CH}$ aliphatic), $1686.44(\mathrm{C}=\mathrm{O})$; ${ }^{1} \mathrm{H}$ NMR $\left(600 \mathrm{MHz}, \mathrm{CDCl}_{3}\right) \delta 7.94(\mathrm{dd}, J=7.8,1.6 \mathrm{~Hz}$, 
FARMACIA, 2018, Vol. 66, 4

1H, CH-5 chroman-4-one), 7.85 (d, $J=8.1 \mathrm{~Hz}, 2 \mathrm{H}$, CH-2', CH-6'), 7.57 - 7.47 (m, 1H, CH-7 chroman4-one), 7.36 (s, 1H, CH-5 thiazole), 7.24 (d, $J=8.0$ $\mathrm{Hz}, 2 \mathrm{H}, \mathrm{CH}-3$ ', CH-5'), 7.11 - 7.03 (m, 2H, CH-6, CH-8 chroman-4-one), 5.73 (dd, $J=11.8,3.4 \mathrm{~Hz}$, 1H, CH-2 chroman-4-one), 3.31 (dd, $J=17.0,11.8$ $\mathrm{Hz}, 1 \mathrm{H}, \mathrm{CH}-3$ chroman-4-one), 3.19 (dd, $J=17.0$, $3.5 \mathrm{~Hz}, 1 \mathrm{H}, \mathrm{CH}-3$ chroman-4-one); ${ }^{13} \mathrm{C}$ NMR (151 $\left.\mathrm{MHz}, \mathrm{CDCl}_{3}\right) \delta 191.70(\mathrm{C}, \mathrm{C}=\mathrm{O}), 169.39(\mathrm{C}, \mathrm{C}-2$ thiazole), 161.09 (C, C-8a chroman-4-one), 154.39 (C, C-4 thiazole), 140.88 (C, C-4'), 136.26 (CH, C-5 thiazole), $130.62(\mathrm{CH}, \mathrm{C}-7$ chroman-4-one), 129.78 (CH, C-3', C-5'), 127.15 (C, C-1'), 126.72 (CH, C-2', C-6'), 121.84 (CH, C-5 chroman-4-one), 121.32 (CH, C-6, chroman-4-one), 118.23 (C, C-4a, chroman-4one), 115.82 (CH, C-8 chroman-4-one), $76.02(\mathrm{CH}$, $\mathrm{C}-2$ chroman-4-one), 42.66 ( $\mathrm{CH}_{2}, \mathrm{C}-3$ chroman-4-one), $21.57\left(\mathrm{C}, \mathrm{CH}_{3}\right)$; $\mathrm{MS}: \mathrm{m} / z 322.5\left[\mathrm{M}+\mathrm{H}^{+}\right]$(calculated for $\mathrm{C}_{19} \mathrm{H}_{15} \mathrm{NO}_{2} \mathrm{~S}^{+}$: 322.09).

2-(2-(4-Chlorophenyl)thiazol-4-yl)chroman-4-one

(4c): Pale-yellow powder; purified by column chromatography (eluent: petroleum ether:ethyl acetate $=$ 9/1 v/v); yield: $40 \%$; mp: $157.3-161^{\circ} \mathrm{C} ; R_{f}=0.28$ (eluent: petroleum ether:ethyl acetate $=9 / 1 \mathrm{v} / \mathrm{v})$. IR: $\bar{v}$ $\left(\mathrm{cm}^{-1}\right): 3100.01$ (CH arom), 2918.73 (CH aliphatic), $1686.44(\mathrm{C}=\mathrm{O}) ;{ }^{1} \mathrm{H}$ NMR $\left(600 \mathrm{MHz}, \mathrm{CDCl}_{3}\right) \delta 7.94$ (dd, $J=7.8,1.7 \mathrm{~Hz}, 1 \mathrm{H}, \mathrm{CH}-5$ chroman-4-one), 7.88 (d, $J=8.5 \mathrm{~Hz}, 2 \mathrm{H}, \mathrm{CH}-2$ ', CH-6'), 7.52 (ddd, $J=8.7,7.3,1.7 \mathrm{~Hz}, 1 \mathrm{H}, \mathrm{CH}-7$ chroman-4-one), 7.41 (d, $J=8.5 \mathrm{~Hz}, 2 \mathrm{H}, \mathrm{CH}-3$ ', CH-5') overlapped with 7.41 (s, 1H, CH-5 thiazole), $7.09-7.05$ (m, 2H, CH-6, CH-8 chroman-4-one), 5.72 (dd, $J=11.7$, $3.5 \mathrm{~Hz}, 1 \mathrm{H}, \mathrm{CH}-2$ chroman-4-one), 3.30 (dd, $J=16.9$, $11.7 \mathrm{~Hz}, 1 \mathrm{H}, \mathrm{CH}-3$ chroman-4-one), 3.18 (dd, $J=16.9$, $3.5 \mathrm{~Hz}, 1 \mathrm{H}, \mathrm{CH}-3$ chroman-4-one); ${ }^{13} \mathrm{C}$ NMR (151 $\left.\mathrm{MHz} \mathrm{CDCl}_{3}\right) \delta 191.60(\mathrm{C}, \mathrm{C}=\mathrm{O}), 167.77(\mathrm{C}, \mathrm{C}-2$ thiazole), 161.00 (C, C-8a chroman-4-one), 154.88 (C, C-4 thiazole), 136.44 (C, C-4'), 136.33 (CH, C-5 thiazole), 131.87 (CH, C-7 chroman-4-one), 129.34 (CH, C-3', C-5'), 127.95 (CH, C-2', C-6'), 127.18 (C, C-1'), 121.92 (CH, C-5 chroman-4-one), 121.31 (CH, C-6 chroman-4-one), 118.21 (C, C-4a chroman-4-one), 116.60 (CH, C-8 chroman-4-one), 75.98 (CH, C-2 chroman-4-one), 42.81 ( $\mathrm{CH}_{2}, \mathrm{C}-3$ chroman-4-one); $\mathrm{MS}$ : $m / z 342.2\left[\mathrm{M}+\mathrm{H}^{+}\right]$(calculated for $\mathrm{C}_{18} \mathrm{H}_{13} \mathrm{ClNO}_{3} \mathrm{~S}^{+}$: $342.04)$.

2-(2-(4-Methoxyphenyl)thiazol-4-yl)chroman-4-one (4d): Pale-yellow powder; purified by column chromatography (eluent: petroleum ether:ethyl acetate $=$ 6/1 v/v); yield: $48 \%$; mp: $141.2-144.6^{\circ} \mathrm{C} ; R_{f}=0.43$ (eluent: petroleum ether:ethyl acetate $=4 / 1 \mathrm{v} / \mathrm{v})$. IR: $\bar{v}$ $\left(\mathrm{cm}^{-1}\right): 3100.01$ (CH arom), 2918.73 (CH aliphatic), 1686.44 (C=O); ${ }^{1} \mathrm{H}$ NMR (600 MHz, $\left.\mathrm{CDCl}_{3}\right) \delta 7.93$ (dd, $J=7.9,1.6 \mathrm{~Hz}, 1 \mathrm{H}, \mathrm{CH}-5$ chroman-4-one), 7.89 (d, $J=8.8 \mathrm{~Hz}, 2 \mathrm{H}, \mathrm{CH}-2$ ', CH-6'), 7.53 - 7.48 (m, 1H, CH-7 chroman-4-one), $7.31(\mathrm{~s}, 1 \mathrm{H}, \mathrm{CH}-5$ thiazole), 7.09 - 7.03 (m, 2H, CH-6, CH-8 chroman- 4-one), 6.94 (d, $J=8.8 \mathrm{~Hz}, 2 \mathrm{H}, \mathrm{CH}-3$ ', CH-5'), 5.71 (dd, $J=11.8,3.4 \mathrm{~Hz}, 1 \mathrm{H}, \mathrm{CH}-2$ chroman-4one), $3.85\left(\mathrm{~s}, 3 \mathrm{H}, \mathrm{OCH}_{3}\right), 3.30(\mathrm{dd}, J=17.0,11.8$ $\mathrm{Hz}, 1 \mathrm{H}, \mathrm{CH}-3$ chroman-4-one), 3.18 (dd, $J=17.0$, $3.5 \mathrm{~Hz}, 1 \mathrm{H}, \mathrm{CH}-3$ chroman-4-one); ${ }^{13} \mathrm{C}$ NMR (151 $\left.\mathrm{MHz}, \mathrm{CDCl}_{3}\right) \delta 191.72(\mathrm{C}, \mathrm{C}=\mathrm{O}), 169.06(\mathrm{C}, \mathrm{C}-2$ thiazole), 161.53 (C, C-4'), 161.09 (C, C-8a chroman4-one), 154.26 (C, C-4 thiazole), 136.24 (CH, C-5 thiazole), 128.63 (CH, C-7 chroman-4-one), 128.31 (CH, C-2', C-6'), 127.13 (C, C-1'), 121.81 (CH, C-5 chroman-4-one), 121.31 ( $\mathrm{CH}, \mathrm{C}-6$ chroman-4-one), 118.23 (C, C-4a chroman-4-one), 115.37 (CH, C-8 chroman-4-one), 114.42 (CH, C-3', C-5'), 76.01 (CH, C-2 chroman-4-one), $55.53\left(\mathrm{C}, \mathrm{OCH}_{3}\right), 42.83$

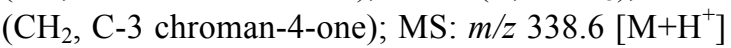
(calculated for $\mathrm{C}_{19} \mathrm{H}_{16} \mathrm{NO}_{3} \mathrm{~S}^{+}: 338.09$ ).

2-(2-Phenylthiazol-4-yl)-4H-chromen-4-one (5a): White powder; purified by column chromatography (eluent: petroleum ether:ethyl acetate $=7 / 1 \mathrm{v} / \mathrm{v}$, after petroleum ether:ethyl acetate $=6: 1 \mathrm{v} / \mathrm{v}$ or dichloromethane, after dichloromethane:acetone $=50: 1 \mathrm{v} / \mathrm{v})$; yield: $45 \%$; mp: $188.7-191.2^{\circ} \mathrm{C} ; R_{f}=0.24$ (eluent: petroleum ether:ethyl acetate $=6: 1 \mathrm{v} / \mathrm{v})$. IR: $\bar{v}\left(\mathrm{~cm}^{-1}\right)$ : 3063.37 (CH arom), 2921.63 (C-H aliphatic), 1606.41 $(\mathrm{C}=\mathrm{O}) ;{ }^{1} \mathrm{H}$ NMR $\left(600 \mathrm{MHz}, \mathrm{CDCl}_{3}\right) \delta 8.24(\mathrm{dd}$, $J=7.9,1.2 \mathrm{~Hz}, 1 \mathrm{H}, \mathrm{CH}-5$ chromen-4-one), 8.04 (s, $1 \mathrm{H}, \mathrm{CH}-5$ thiazole), 8.01 (dd, $J=6.5,2.9 \mathrm{~Hz}, 2 \mathrm{H}$, CH-2', CH-6'), 7.72 - 7.69 (m, 1H, CH-7), 7.55 (d, $J=8.3 \mathrm{~Hz}, 1 \mathrm{H}, \mathrm{CH}-8$ chromen-4-one), 7.50 - 7.47 (m, 3H, CH-3', CH-4', CH-5'), 7.42 (t, $J=7.5 \mathrm{~Hz}, 1 \mathrm{H}$, CH-6 chromen-4-one), 7.39 (s, 1H, CH-3 chromen-4one); $\left.{ }^{13} \mathrm{C} \mathrm{NMR} \mathrm{(151} \mathrm{MHz,} \mathrm{CDCl}_{3}\right) \delta 178.82(\mathrm{C}$, $\mathrm{C}=\mathrm{O}), 169.42$ (C, C-2 thiazole), 158.71 (C, C-8a chromen-4-one), 156.21 (C, C-2 chromen-4-one), 148.74 (C, C-4 thiazole), 134.09 (C, C-1'), 132.83 (CH, C-5 thiazole), 131.03 (CH, C-7 chromen-4-one), 129.26 (CH, C-3', C-5'), 126.91 (CH, C-2', C-6'), 126.01 (CH, C-4'), 125.48 (CH, C-5 chromen-4one), 124.25 (CH, C-6 chromen-4-one), 120.41 (C, C-4a chromen-4-one), 118.11 (CH, C-8 chromen-4one), 108.64 ( $\mathrm{CH}, \mathrm{C}-3$ chromen-4-one); $\mathrm{MS}: \mathrm{m} / \mathrm{z}$ $306.4\left[\mathrm{M}+\mathrm{H}^{+}\right]$(calculated for $\mathrm{C}_{18} \mathrm{H}_{12} \mathrm{NO}_{2} \mathrm{~S}^{+}: 306.06$ ). 2-(2-(p-Tolyl)thiazol-4-yl)-4H-chromen-4-one (5b): White powder; purified by column chromatography (eluent: petroleum ether:ethyl acetate $=4 / 1 \mathrm{v} / \mathrm{v}$ ); yield: 55\%; mp: $157.8-161.1^{\circ} \mathrm{C} ; R_{f}=0.34$ (eluent: petroleum ether:ethyl acetate $=4: 1 \mathrm{v} / \mathrm{v})$. IR: $\bar{v}\left(\mathrm{~cm}^{-1}\right) 3113.51$ (CH arom), 2920.66 (C-H aliphatic), $1606.41(\mathrm{C}=\mathrm{O})$; ${ }^{1} \mathrm{H}$ NMR $\left(600 \mathrm{MHz}, \mathrm{CDCl}_{3}\right) \delta 8.25-8.21(\mathrm{~m}, 1 \mathrm{H}$, $\mathrm{CH}-5$ chromen-4-one), 8.00 (s, 1H, CH-5 thiazole), 7.89 - 7.86 (m, 2H, CH-2', CH-6'), 7.72 - 7.68 (m, $1 \mathrm{H}, \mathrm{CH}-7$ chromen-4-one), $7.56-7.53(\mathrm{~m}, 1 \mathrm{H}, \mathrm{CH}-8$ chromen-4-one), 7.44 - 7.38 (m, 2H, CH-6, CH-3 chromen-4-one), 7.28 - 7.24 (m, 2H, CH-3', CH-5'), $2.40\left(\mathrm{~s}, 3 \mathrm{H}, \mathrm{CH}_{3}\right) ;{ }^{13} \mathrm{C} \mathrm{NMR}\left(151 \mathrm{MHz}, \mathrm{CDCl}_{3}\right) \delta$ $178.84(\mathrm{C}, \mathrm{C}=\mathrm{O}), 169.59$ (C, $\mathrm{C}-2$ thiazole), 158.92 (C, C-8a chromen-4-one), 156.20 (C, C-2 chromen- 
FARMACIA, 2018, Vol. 66, 4

4-one), 148.45 (C, C-4'), 141.46 (C, C-4 thiazole), 134.17 (CH, C-5 thiazole), 130.16 (C, C-1'), 129.90 (CH, C-3', C-5'), 126.81 (CH, C-2', C-6'), 125.97 (CH, C-7 chromen-4-one), 125.50 (CH, C-5 chromen4-one), 124.04 ( $\mathrm{CH}, \mathrm{C}-6$ chromen-4-one), 120.25 (C, C-4a chromen-4-one), 118.12 (CH, C-8 chromen-4one), 108.40 ( $\mathrm{CH}, \mathrm{C}-3$ chromen-4-one), $21.63\left(\mathrm{CH}_{3}\right)$; MS: $m / z 320.5\left[\mathrm{M}+\mathrm{H}^{+}\right]$(calculated for $\mathrm{C}_{19} \mathrm{H}_{14} \mathrm{NO}_{2} \mathrm{~S}^{+}$: 320.07).

2-(2-(4-Chlorophenyl)thiazol-4-yl)-4H-chromen-4-one (5c): White powder; purified by column chromatography (eluent: petroleum ether:ethyl acetate $=6 / 1 \mathrm{v} / \mathrm{v}$ or dichloromethane, after dichloromethane:acetone $=50 / 1$ v/v); yield: $39 \%$; mp: $197.6-201.2^{\circ} \mathrm{C} ; R_{f}=0.27$ (eluent: petroleum ether:ethyl acetate $=6 / 1 \mathrm{v} / \mathrm{v}$ ). IR: $\bar{v}\left(\mathrm{~cm}^{-1}\right) 2922.59(\mathrm{CH}$ arom), $1606.41(\mathrm{C}=\mathrm{O})$; ${ }^{1} \mathrm{H} \mathrm{NMR}\left(600 \mathrm{MHz}, \mathrm{CDCl}_{3}\right) \delta 8.24(\mathrm{dd}, J=7.9,1.2 \mathrm{~Hz}$, $1 \mathrm{H}, \mathrm{CH}-5$ chromen-4-one), 8.06 (s, 1H, CH-5 thiazole), $7.93\left(\mathrm{~d}, J=8.5 \mathrm{~Hz}, 2 \mathrm{H}, \mathrm{CH}-2{ }^{\prime}, \mathrm{CH}-6\right.$ '), 7.72 (t, $J=$ $7.7 \mathrm{~Hz}, 1 \mathrm{H}, \mathrm{CH}-7$ chromen-4-one), 7.56 (d, $J=8.4$ $\mathrm{Hz}, 1 \mathrm{H}, \mathrm{CH}-8$ chromen-4-one), 7.44 (d, $J=8.4 \mathrm{~Hz}$, 2H, CH-3', CH-5'), 7.43 - 7.40 (m, 2H, CH-3, CH-6 chromen-4-one); ${ }^{13} \mathrm{C}$ NMR (151 MHz, $\left.\mathrm{CDCl}_{3}\right) \delta$ $178.81(\mathrm{C}, \mathrm{C}=\mathrm{O}), 168.10$ (C, $\mathrm{C}-2$ thiazole), 158.73 (C, C-8a chromen-4-one), 156.20 (C, C-2 chromen4-one), 148.77 (C, C-4 thiazole), 137.12 (C, C-4'), 134.32 (C, C-1'), 131.24 (CH, C-5 thiazole), 129.52 (CH, C-3', C-5'), 128.08 (CH, C-2', C-6'), 126.01 (CH, C-7 chromen-4-one), 125.65 (CH, C-5 chromen-4one), 123.97 (CH, C-6 chromen-4-one), 120.85 (C, C-4a chromen-4-one), 118.13 (CH, C-8 chromen-4one), 108.47 (CH, C-3 chromen-4-one); MS: m/z 340.6 $\left[\mathrm{M}+\mathrm{H}^{+}\right]$(calculated for $\mathrm{C}_{18} \mathrm{H}_{11} \mathrm{ClNO}_{2} \mathrm{~S}^{+}: 340.02$ ). 2-(2-(4-Methoxyphenyl)thiazol-4-yl)-4H-chromen4-one (5d): White powder; purified by column chromatography (eluent: petroleum ether:ethyl acetate $=$ $4 / 1 \mathrm{v} / \mathrm{v}$, after petroleum ether:ethyl acetate $=3 / 1 \mathrm{v} / \mathrm{v}$ ); yield: $32 \%$; mp: $183.6-186.4^{\circ} \mathrm{C} ; \mathrm{R}_{f}=0.40$ (eluent: petroleum ether:ethyl acetate $=4 / 1 \mathrm{v} / \mathrm{v})$. IR: $\bar{v}\left(\mathrm{~cm}^{-1}\right)$ : 3142.44 (CH arom), 2923.56 ( $\mathrm{CH}$ aliphatic), 1607.38 $(\mathrm{C}=\mathrm{O}) ;{ }^{1} \mathrm{H} \mathrm{NMR}\left(600 \mathrm{MHz}, \mathrm{CDCl}_{3}\right) \delta 8.24(\mathrm{dd}$,
$J=7.9,1.5 \mathrm{~Hz}, 1 \mathrm{H}, \mathrm{CH}-5$ chromen-4-one), 7.95 (s, $1 \mathrm{H}, \mathrm{CH}-5$ thiazole) overlapped with $7.94(\mathrm{~d}, J=8.9 \mathrm{~Hz}$, 2H, CH-2', CH-6'), 7.69 (ddd, $J=8.6,7.2,1.6 \mathrm{~Hz}, 1 \mathrm{H}$, CH-7 chromen-4-one), 7.54 (d, $J=8.2 \mathrm{~Hz}, 1 \mathrm{H}, \mathrm{CH}-8$ chromen-4-one), 7.45 - 7.37 (m, 1H, CH-6 chromen4-one), 7.31 (s, 1H, CH-3 chromen-4-one), 6.98 (d, $J=8.8 \mathrm{~Hz}, 2 \mathrm{H}, \mathrm{CH}-3$ ', CH-5'), 3.88 (s, 3H, $\left.\mathrm{OCH}_{3}\right)$; ${ }^{13} \mathrm{C}$ NMR $\left(151 \mathrm{MHz}, \mathrm{CDCl}_{3}\right) \delta 178.81(\mathrm{C}, \mathrm{C}=\mathrm{O})$, 169.17 (C, C-2 thiazole), 161.89 (C, C-4'), 158.51 (C, C-8a chromen-4-one), 156.19 (C, C-2 chromen-4-one), 148.58 (C, C-4 thiazole), 133.87 ( $\mathrm{CH}, \mathrm{C}-5$ thiazole), 128.44 (CH, C-2', C-6'), 125.98 (CH, C-7 chromen4-one), 125.82 (C, C-1'), 125.31 (CH, C-5 chromen4-one), 124.48 (CH, C-6 chromen-4-one), 119.31 (C, C-4a chromen-4-one), 118.08 (CH, C-8 chromen-4one), 114.56 (CH, C-3', C-5'), 108.75 (CH, C-3 chromen-4-one), $55.61\left(\mathrm{C}, \mathrm{OCH}_{3}\right)$; $\mathrm{MS}: \mathrm{m} / z 336.4$ $\left[\mathrm{M}+\mathrm{H}^{+}\right]$(calculated for $\mathrm{C}_{19} \mathrm{H}_{14} \mathrm{NO}_{3} \mathrm{~S}^{+}$: 336.07).

Evaluation of the antioxidant activity for the synthesized compounds

Among the methods used for testing the in vitro antioxidant activity, the best known is the neutralization of free DPPH radicals. DPPH molecule is a stable free radical that not dimerize due to the effect of free electron delocalization [2].

The antioxidant activities were calculated using the formula:

$$
\mathrm{I} \%=\left[\left(\mathrm{A}_{\text {control }}-\mathrm{A}_{\text {sample }}\right) / \mathrm{A}_{\text {control }}\right] * 100,
$$

where: $A_{\text {control }}=$ the absorbance measured for the mixture of DPPH and solvent (methanol/dichloromethane), and $\mathrm{A}_{\text {sample }}=$ the absorbance measured for the mixture of DPPH and compound and solvent (methanol/dichloromethane).

The determined antioxidant activities for standards, thiazole chalcones, flavanones and flavones are shown in Tables IV and V.

The obtained results were compared with the standards, ascorbic acid and quercetin, and the antioxidant activity was calculated with the formula:

$\%$ Antioxidant activity $=\left(\mathrm{I}_{\text {compound }} / \mathrm{I}_{\text {standard }}\right) * 100$.

Table IV

Antioxidant activity (I\%) for chalcones, flavanones, flavones and standards

\begin{tabular}{|cccc|}
\hline Compound & Solvent & Concentration $(\boldsymbol{\mu m o l} / \mathbf{m L})$ & $\mathbf{I \%}$ average \\
\hline $\mathbf{3 a}$ & Methanol & 0.085 & 0.0497 \\
\hline $\mathbf{3 b}$ & Methanol & 0.085 & 0.0500 \\
\hline $\mathbf{3 c}$ & Methanol & 0.085 & 0.0462 \\
\hline $\mathbf{3 d}$ & Methanol & 0.060 & 0.0406 \\
\hline $\mathbf{3 e}$ & Dichloromethane & 0.060 & 0.0223 \\
\hline $\mathbf{3 f}$ & Dichloromethane & 0.060 & 0.0217 \\
\hline $\mathbf{3 g}$ & Dichloromethane & 0.060 & 0.0340 \\
\hline $\mathbf{3 h}$ & Dichloromethane & 0.060 & 0.0228 \\
\hline $\mathbf{4 a}$ & Dichloromethane & 0.060 & 0.0211 \\
\hline $\mathbf{4 b}$ & Dichloromethane & 0.060 & 0.0310 \\
\hline $\mathbf{4 c}$ & Dichloromethane & 0.060 & 0.0260 \\
\hline $\mathbf{4 d}$ & Dichloromethane & 0.060 & 0.0252 \\
\hline $\mathbf{5 a}$ & Dichloromethane & 0.060 & 0.0093 \\
\hline $\mathbf{5 b}$ & Dichloromethane & 0.060 & 0.0400 \\
\hline
\end{tabular}


FARMACIA, 2018, Vol. 66, 4

\begin{tabular}{|cccc|}
\hline Compound & Solvent & Concentration $(\boldsymbol{\mu m o l} / \mathbf{m L})$ & I\% average \\
\hline 5c & Dichloromethane & 0.060 & 0.0340 \\
\hline 5d & Dichloromethane & 0.060 & 0.0078 \\
\hline Ascorbic acid & Methanol & 0.085 & 99.35 \\
\hline Ascorbic acid & Dichloromethane & 0.060 & 90.48 \\
\hline Quercetin & Methanol & 0.085 & 90.80 \\
\hline Quercetin & Dichloromethane & 0.060 & 52.06 \\
\hline
\end{tabular}

Table V

$\%$ Antioxidant activity of compounds related to ascorbic acid and quercetin

\begin{tabular}{|ccc|}
\hline Compound & \% Antioxidant activity related to ascorbic acid & \% Antioxidant activity related to quercetin \\
\hline $\mathbf{3 a}$ & 0.0498 & 0.0546 \\
\hline $\mathbf{3 b}$ & 0.0500 & 0.0548 \\
\hline $\mathbf{3 c}$ & 0.0465 & 0.0510 \\
\hline $\mathbf{3 d}$ & 0.0408 & 0.0446 \\
\hline $\mathbf{3 e}$ & 0.0247 & 0.0431 \\
\hline $\mathbf{3 f}$ & 0.0239 & 0.0416 \\
\hline $\mathbf{3 g}$ & 0.0376 & 0.0653 \\
\hline $\mathbf{3 h}$ & 0.0252 & 0.0438 \\
\hline $\mathbf{4 a}$ & 0.0233 & 0.0461 \\
\hline $\mathbf{4 b}$ & 0.0342 & 0.0595 \\
\hline $\mathbf{4 c}$ & 0.0287 & 0.0498 \\
\hline $\mathbf{4 d}$ & 0.0218 & 0.0378 \\
\hline $\mathbf{5 a}$ & 0.0103 & 0.0178 \\
\hline $\mathbf{5 b}$ & 0.0443 & 0.0768 \\
\hline $\mathbf{5 c}$ & 0.0038 & 0.0065 \\
\hline $\mathbf{5 d}$ & 0.0081 & 0.0140 \\
\hline
\end{tabular}

For the synthesized thiazole hydroxychalcones, the antioxidant capacity varied between $0.0217 \%$ and $0.05 \%$. The highest potential in the hydroxychalcone series has the compound $\mathbf{3 b}$ with a $p$-tolyl group on the thiazole ring of the aldehyde and a hydroxyl group in the para position of acetophenone. For this compound, the antioxidant activity represents $0.05 \%$ of the ascorbic acid activity and $0.0548 \%$ of the quercetin activity.

In the thiazole flavanones series, the antioxidant activity ranged from $0.0211 \%$ to $0.031 \%$. Flavanone $\mathbf{4 b}$, derived from $p$-tolyl thiazole, presented the highest antioxidant activity $(0.0342 \%$ of the ascorbic acid antioxidant activity and $0.0595 \%$ of the quercetin activity).

The antioxidant activity of thiazole flavones varied between $0.0078 \%$ and $0.04 \%$. The best antioxidant capacity was found for the flavone substituted with a $p$-tolyl group on the thiazole ring (compound $\mathbf{5 b}$ ). It has $0.0443 \%$ of the ascorbic acid antioxidant activity and $0.0768 \%$ of the quercetin activity.

Among the synthesized compounds, the highest activity has the chalcone $\mathbf{3 b}$ containing a $p$-tolyl group on the thiazole ring and a hydroxyl group in the para position of the benzene ring coming from acetophenone. From the synthesized compounds, flavones have the weakest antioxidant activity.

Among the analysed series of compounds, thiazole chalcones are presenting the highest activity and thiazole flavones the less. It was found that the presence of the para tolyl group on the thiazole moiety of chalcones determined a slight increase of the DPPH scavenging activity.

Thiazole chalcones, flavanones and flavones have a low antioxidant activity.

\section{Conclusions}

We have synthesized a series of hydroxychalcones and their corresponding flavanones and flavones derivatives to assess their antioxidant potential.

Ortho hydroxychalcones were cyclized in acidic or basic catalysis to the corresponding thiazole flavanones. The most effective method for obtaining flavanones is the cyclization with sulfuric acid in ethanol at $100^{\circ} \mathrm{C}$. Thiazole flavones were synthesized by oxidative cyclization with iodine in dimethyl sulfoxide.

Spectral analysis ${ }^{1} \mathrm{H}$ NMR, ${ }^{13} \mathrm{C}$ NMR, IR and MS confirmed the structure of the synthesized compounds. It was determined the antioxidant activity of thiazole chalcones, flavanones and flavones by DPPH method. The synthesized compounds have a low antioxidant activity.

The synthesized compounds are currently evaluated for their anticancer and antimicrobial potential.

\section{Acknowledgement}

This work was support by the University of Medicine and Pharmacy "Iuliu Haţieganu", Cluj-Napoca, Romania, internal grant no. 7690/27/04.15.2016. 


\section{References}

1. Adefegha SA, Leal DBR, Doleski PH, Ledur PC, Ecker A, Peripheral blood mononuclear cell from rat model of pleurisy: The effects of hesperidin on ectoenzymes activity, apoptosis, cell cycle and reactive oxygen species production. Biomed Pharmacother., 2017; 91: 278-286.

2. Alam N, Bristi NJ, Rafiquzzaman Md, Review on in vivo and in vitro methods evaluation of antioxidant activity. Saudi Pharm J., 2013; 21(2): 143-152.

3. Awoussoung PK, Zaharia V, Ngameni B, Kuete V, Ntede HN, Fokunang CN, Abegaz BM, Heterocycles 26: synthesis, characterization, and anticancer activity of some thiazolic chalcones. Med Chem Res., 2015; 24: 131-141.

4. Bano S, Javed K, Ahmad S, Rathish IG, Singh S, Chaitanya M, Arunasree KM, Alam MS, Synthesis of some chalcones, flavanones and flavones and evaluation of their anti-inflammatory activity. Eur $J$ Med Chem., 2013; 65: 51-59.

5. Blois MS, Antioxidant determinations by the use of a stable free radical. Nature, 1958; 181: 1999-2000.

6. Boots AW, Haenen GR, Bast A, Health effects of quercetin: from antioxidant to nutraceutical. Eur $J$ Pharmacol., 2008; 585(2-3): 325-327.

7. Cabrera M, Simoens M, Falchi G, Lavaggi ML, Piro OE, Castellano EE, Vidal A, Azqueta A, Monge A, López de Ceráin A, Sagrera G, Seoane G, Cerecetto $\mathrm{H}$, González M, Synthetic chalcones, flavanones, and flavones as antitumoral agents: Biological evaluation and structure-activity relationships. Bioorg Med Chem., 2007; 15(10): 3356-3367.

8. Chand K, Rajeshwari, Hiremathad A, Singh M, Santos MA, Keriab RS, A review on antioxidant potential of bioactive heterocycle benzofuran: Natural and synthetic derivatives. Pharmacol Rep., 2017; 69(2): 281-295.

9. Cheng ZJ, Kuo SC, Chan SC, Ko FN, Teng CM, Antioxidant properties of butein isolated from Dalbergia odorifera. Biochim Biophys Acta - Lipids and Lipid Metabolism, 1998; 1392(2-3): 291-299.

10. Chimenti F, Fioravanti R, Bolasco A, Chimenti P, Secci D, Rossi F, Yáñez M, Orallo F, Ortuso F, Alcaro S, Cirilli R, Ferretti R, Sanna ML, A new series of flavones, thioflavones, and flavanones as selective monoamine oxidase-B inhibitors. Bioorg Med Chem., 2010; 18(3): 1273-1279.

11. Jaishree V, Ramdas N, Sachin J, Ramesh B, In vitro antioxidant properties of new thiazole derivatives. $J$ Saudi Chem Soc., 2012; 16: 371-376.

12. Kavala V, Lin C, Kuo CW, Fang H, Yao CF, Iodine catalyzed one pot synthesis of flavanone and tetra hydropyrimidine derivatives via Mannich type reaction. Tetrahedron, 2012; 68(4): 1321-1329.

13. Leonte $\mathrm{D}$, Bencze LC, Tőtős $\mathrm{R}$, Zaharia $\mathrm{V}$, Heterocycles 41. Synthesis and characterisation of new thiazole $\beta$-amino acids and $\beta$-amino esters. Farmacia, 2017; 65(2): 207-213.
14. Mager S, Zaharia V, Horn M, Simiti I, Heterocyclen 69. Mitt.: Das Verhalten einiger orto-hydroxy-hetero chalcone under dem einvirkung von hydrazinen. Arch Pharm (Weinheim), 1992; 325: 613-615.

15. Mahapatra DK, Bharti SK, Asati V, Anti-cancer chalcones: Structural and molecular target perspectives. Eur J Med Chem., 2015; 98: 69-114.

16. Mondal R, Gupta AD, Mallik AK, Synthesis of flavanones by use of anhydrous potassium carbonate as an inexpensive, safe, and efficient basic catalyst. Tetrahedron Lett., 2011; 52: 5020-5024.

17. Prasath R, Bhavana P, Sarveswari S, Ng SW, Edward RT, Tiekink ERT, Efficient ultrasound-assisted synthesis, spectroscopic, crystallographic and biological investigations of pyrazole-appended quinolinyl chalcones. $J \mathrm{Mol}$ Struct., 2015; 1081: 201-210.

18. Raghav N, Kaur R, Chalcones, semicarbazones and pyrazolines as inhibitors of cathepsins $\mathrm{B}, \mathrm{H}$ and $\mathrm{L}$. Int J Biol Macromol., 2015; 80: 710-724.

19. Safavi M, Esmati N, Ardestani SK, Emami S, Ajdari S, Davoodi J, Shafiee A, Foroumadi A, Halogenated flavanones as potential apoptosis-inducing agents: Synthesis and biological activity evaluation. Eur $J$ Med Chem., 2012; 58: 573-580.

20. Sarojini BK, Krishna BG, Darshanraj CG, Bharath $\mathrm{BR}$, Manjunatha $\mathrm{H}$, Synthesis, characterization, in vitro and molecular docking studies of new 2,5dichloro thienyl substituted thiazole derivatives for antimicrobial properties. Eur J Med Chem., 2010; 45(8): 3490-3496.

21. Shenvi S, Kumar K, Hatti KS, Rijesh K, Diwakar L, Reddy GC, Synthesis, anticancer and antioxidant activities of 2,4,5-trimethoxy chalcones and analogues from asaronaldehyde: structure-activity relationship. Eur J Med Chem., 2013; 62: 435-442.

22. Silberg A, Simiti I, Mantsch H, Beiträge zum Studium der Thiazole, I Über die Herstellung und die Eigenschaften von 2-Aryl-4-halogenmethyl-thiazolen. Chem Ber., 1961; 94: 2887-2893.

23. Soares M, Brito AF, Laranjo M, Paixão JA, Botelho MF, Pinho e Melo TM, Chiral 6,7-bis(hydroxy methyl)1H,3H-pyrrolo[1,2-c]thiazoles with anti-breast cancer properties. Eur J Med Chem., 2013; 60: 254-262.

24. Venkatachalam H, Nayak Y, Jayashree BS, Synthesis, characterization and antioxidant activities of synthetic chalcones and flavones. APCBEE Procedia, 2012; 3: 209-213.

25. Wang G, Xue Y, An L, Zheng Y, Dou Y, Zhang L, Liu $Y$, Theoretical study on the structural and antioxidant properties of some recently synthesized 2,4,5-trimethoxychalcones. Food Chem., 2015; 171: 89-97.

26. Yamali C, Ozgun DO, Gul HI, Sakagami H, Kazaz C, Okudaira N, Synthesis and structure elucidation of 1(2,5/3,5-difluorophenyl)-3-(2,3/2,4/2,5/3,4-dimethoxyphenyl)-2-propen-1-ones as anticancer agents. Med Chem Res., 2017; 26(9): 2015-2023. 